\title{
Kirjallisilla merkityksillä kuormitettu kaupunki
}

\section{Hannu Raittilan Canal Grande ja tradition kerrostumat}

Hannu Raittilan Venetsiaan sijoittuva romaani Canal Grande (200I) on läpeensä intertekstuaalinen. Se viittaa paitsi tunnettuun Venetsia-kirjallisuuteen myös lukemattomiin taideteoksiin ja kulttuurihistoriallisiin kerrostumiin. Artikkelissa tutkitaan Canal Granden kirjallisen näyttämön ja romaanin tematiikan välistä yhteyttä sekä henkilöhahmojen kytkeytymistä commedia dell'arte -perinteeseen, johon romaani viittaa suoraan paitsi henkilöiden välisissä keskusteluissa myös kuvaamalla Venetsian karnevaalia.

"Venetsiassa ei voi saada mitään aikaiseksi, siellä voi vain oleilla. - - Miksi Venetsiaan tullaan? Onhan kuoleminen ainoa asia, jonka täällä pystyy tekemään muuttaakseen vallitsevaa olotilaa." Näin kirjoittaa päiväkirjaansa Saraspää, yksi Hannu Raittilan Canal Grande -romaanin (200I, viitteissä CG) keskeisistä henkilöistä. ${ }^{1}$ Samalla hän tulee ennakoineeksi oman kohtalonsa tiedostaen samalla, miten kliseiseltä se kuulostaa: "Herra jumala, kuolema Venetsiassa on niin teatraalinen ja kirjallisilla merkityksillä tukahdutettu aihe, että sen ajatteleminenkin herättää ärtymystä.” (CG, 33.)

Canal Grande on täynnä viittauksia paitsi kirjallisuuteen myös muihin taiteisiin: musiikkiin, elokuvaan, kuvataiteeseen ja arkkitehtuuriin. Viittausten kohteina ovat yhtä hyvin Venetsian kirkot ja Tintoretton maalaukset kuin Antti Hyryn proosa, James Bond -elokuvat tai Veikko Lavin laulelmat. Keskeisenä pohjatekstinä on Thomas Mannin tunnettu pienoisromaani Kuolema Venetsiassa (Der Tod in Venedig, 1912, suom. 1928), johon alun katkelmassakin viitataan, mutta romaani yhdistelee maailmankirjallisuuden merkkiteoksiin häikäilemättä myös populaarikulttuurin tuotoksia. Canal Granden tarina sijoittuu pääosin Venetsiaan, joka jo itsessään on ainutlaatuinen kokonaistaideteos. Joillekin romaanihenkilöille maailman taideaarteet ovat läpikotaisin tuttuja, jotkut kuulevat niistä ensimmäistä kertaa. Tästä epäsuhdasta syntyy myös komiikkaa, jolla on tärkeä funktio erityisesti kansallisten stereotypioiden ja eteläpohjoinen-vastakohtaisuuksien käsittelyssä. Henkilöiden suhde taiteeseen ja Venetsian aarteisiin muodostaa vain yhden romaanin monista kerroksista. Raittila tarttuu myös maailmanlaajuisiin ongelmiin kuten

\footnotetext{
${ }^{1}$ Romaanin nimi on nimiölehdellä muodossa Canal Grande eli ensimmäinen sana on kursivoitu syystä, jota en tässä lähde selvittämään. Selvyyden vuoksi kursivoin koko nimen erotukseksi Venetsian pääväylästä, joka esiintyy Raittilan romaanissa pääosin alkukielisessä muodossaan. Canal Grandesta on käytetty myös suomenkielistä nimitystä Suuri kanava, joka esiintyy esimerkiksi Hemingwayn suomennoksessa Joen yli puiden siimekseen (Across the River and into the Trees 1950, suom. 195I). Suomenkielinen nimi vilahtaa myös Raittilan romaanissa (CG, 9), minkä voi tulkita alluusioksi juuri Hemingwayn romaaniin, johon viitataan toisaalla myös suoraan (CG, 62).
} 
valtapolitiikkaan, korruptioon sekä kansalliset rajat ylittävään rikollisuuteen, esimerkiksi salakuljetukseen ja ihmiskauppaan.

Henkilöhahmojen tietämyksen epäsuhtaisuus tuottaa komiikkaa mutta se tarjoaa myös keinon välittää tietoa niistä kulttuurisista ja kirjallisista kerrostumista, joiden varaan koko romaani rakentuu. Historiallisen perspektiivin keskeisille teemoille tarjoaa tapahtumapaikka, joka lienee myyttisin kaupunki koko maailmassa.

Tässä artikkelissa tutkin Canal Granden kirjallisen näyttämön ja romaanin tematiikan välistä yhteyttä ja siihen liittyen keskeisten henkilöhahmojen kytkeytymistä commedia dell'arte -perinteeseen, johon romaani viittaa suoraan paitsi henkilöiden välisissä keskusteluissa myös kuvaamalla Venetsian karnevaalia.

\section{Suomalaiset Venetsian talvessa}

Tarinan alussa eri alojen asiantuntijoista koottu, EU:n ja Unescon alaisena toimiva suomalaisryhmä saapuu Venetsiaan käynnistämään projektia, jonka päämääränä on ei enempää eikä vähempää kuin kaupungin pelastaminen. Tarkoitus on pysäyttää rakennusten, infrastruktuurin ja taideaarteiden vähittäinen tuhoutuminen. Asiantuntijoiden aika kuluu kuitenkin selvitellessä sitä, mikä heidän todellinen roolinsa on. Onko heille lopultakin varattu pelkkä aasin osa suuressa karnevaalissa, jossa naamioita ei koskaan riisuta - korkeintaan vaihdetaan toisiin? Ryhmän jäsenet joutuvat tekemisiin paitsi oikeiden naamiaisten myös oikean aasin kanssa, kun Venetsian karnevaali toden teolla käynnistyy. Kertomuksen konkreettinen ja allegorinen taso lankeavat näin yhteen.

Canal Grandessa ketään ei voi nimetä päähenkilöksi, vaan kyse on kollektiivin kuvauksesta. Ryhmän rakennusteknisenä asiantuntijana häärii diplomi-insinööri Marrasjärvi, "oikea väärentämätön Suomen mies", kuten kulttuuriasioiden ekspertiksi palkattu Saraspää häntä luonnehtii. Saraspää itse on "Suomessa ainutlaatuinen kosmopoliitti ja eurooppalaisen hengenelämän tuntija". Tämän arvion lausuu koko ryhmän puheenjohtaja, opetusministeriön osastopäällikkö, kulttuuriasiainneuvos Snell, jonka nimen voi tulkita alluusioksi suomalaiseen suurmieheen J. V. Snellmaniin; nimestä puuttuu vain miehinen loppuliite. Ponnekkaan rouvan sydämellä on Venetsian pelastamisen sijasta Suomi-kuvan kirkastaminen ja sen ohella tarve saada projektin rahat kulumaan - budjetin alittaminen on vakavin virhe, johon hankkeessa voi syyllistyä (CG, 316).

Neljäs asiantuntija on Suomen akatemian vanhempi tutkija, yleisen historian dosentti Heikkilä. Marrasjärvi käyttää häntä apupoikanaan virtausmittauksissa ja tulkkinaan italialaisten kassa. Heikkilä tosin ei osaa italiaa, mutta tulee ymmärretyksi latinallaan. Hän on kävelevä ensyklopedia, jota Saraspää luonnehtii akateemisen vanhanpojan perikuvaksi. Vesa Karosen (200I) mukaan Marrasjärvi-nimi viittaa eräkirjailija, kenraali Kurt Martti Walleniuksen asuinpaikkaan Lapissa. Saraspään nimi puolestaan viittaa Inarissa asustavaan eräkirjailijaan Seppo Saraspäähän. Alluusiot suomalaiseen erä- ja Lapin-kirjallisuuteen - olkoonkin että tulevat 
mutkan kautta - voi tulkita sekä omalaatuiseksi huumoriksi että romaanin tematiikkaan liittyvän pohjoinen-etelävastakohtaisuuden rakennuspalikoiksi.

Valtuuskunnan apulaiseksi on palkattu Tuuli, koulunsa kesken jättänyt nuori nainen, joka on ollut Italiassa jo pari vuotta ja jonka harteille kaikki käytännön asiat jäävät. Tuulin asemaa kuvaa se, että asiantuntijoista puhutaan pelkästään sukunimillä, mutta Tuulia kutsutaan aina etunimellä. Hän on kaikista työyhteisöistä tuttu tyttö, jota ilman organisaatiot halvaantuisivat, aikataulut pettäisivät ja palaverikahvit jäisivät keittämättä mutta jonka arvo mitataan vain miesten katseitten määrällä. Canal Grandessakin Tuuli mainitaan ensimmäisen kerran vasta sivulla 52, vaikka hän on ollut paikalla alusta saakka. Kuvaa täydentää se, että Saraspää mieltää hänet alusta alkaen nimenomaan "tytöksi”, vieläpä varsin ihastuttavaksi.

Tuuli on yksi tarinan kolmesta minäkertojasta, kaksi muuta ovat Marrasjärvi ja Saraspää. He ovat tarinaan osallistuvia henkilökertojia, ja heidän sanomisensa voivat olla keskenään ristiriitaisia ja tilannesidonnaisia. Kukin heistä tulkitsee tapahtumat ja tapahtumapaikat omasta erityisestä näkökulmastaan, hyvin subjektiivisesti. Myös heidän tietämyksensä on rajoittunutta. Marrasjärvelle selviää vasta sitten, kun häntä ammutaan sekä haulikolla että kranaatinheittimellä, että he ovat olleet tekemisissä rikollisliigan jäsenten kanssa. Saraspäälle asioiden oikea laita selviää paljon nopeammin, ja Tuuli on tiennyt sen tarinan alusta saakka.

Romaanissa on kaksi osaa, joista ensimmäinen, "Talvi", käsittää suurimman osan koko teoksesta. Jälkiosa "Kevät" on laajuudeltaan ikään kuin talvisen tarinan lyhyt jälkinäytös. Puolitoista kuukautta käsittävän talvitarinan kertomisesta vastaavat vuorovedoin Marrasjärvi ja Saraspää, jotka muutaman sivun mittaisissa kuvauksissa kertovat vuorotellen samoista tapahtumista. "Kevät" on pelkästään Tuulin kerrontaa. Tämä on sikäli yllättävää, että hän vaikuttaa ensimmäisessä osassa sivuhenkilöltä, jonka toimet liittyvät paikallisten kanssa asioimiseen, osin hämäriinkin puuhiin, ja tarinan edetessä hänestä tulee enenevässä määrin Saraspään pakkomielteisen intohimon kohde. Vasta Tuulin omassa kertomuksessa moni oudolta vaikuttava toiminta saa selityksensä ja koko tarina kääntyy ikään kuin nurin.

Romaanin rakenne henkilöineen ja kerrontaratkaisuineen on tapahtumakaupungin kaltainen: monikerroksinen, sokkeloinen, yllättävä. Analogian rakenteelle luo myös tarinan alkua hallitseva sankka sumuverho, jonka suojasta putkahtelee aina uusia piirteitä arvoituksellisesta kaupungista, kunnes tuuli työntää sumupatjan liikkeelle ja asiat näyttäytyvät aivan toisenlaisessa valossa (CG, 32).

\section{Paikan ja henkilöhahmojen monilähtöisyys}

Romaanin tapahtumapaikalla ja -ajalla on yleensä jokin merkitys tematiikan kannalta. Venetsia on yksi kulttuurisesti kuormitetuimmista paikoista maailmassa, ja kun siihen lisätään vielä yhden päähenkilön kuolema, kokonaisuus voisi rakentua kirjallisten kliseiden kierrätyskeskukseksi. 
Romaani kuitenkin rakentuu kliseille tietoisesti, niitä alleviivaten, kuten artikkelin alussa siteeratusta Saraspään päiväkirjamerkinnästä käy ilmi. Ja kliseissä ja stereotypioissa saattaa olla totuus haudattuna. Ei jonkin seikan toistuminen ja toistaminen tee siitä läpeensä sepitteellistä.

Kliseet toimivatkin Raittilalla koodin tavoin. Ne avaavat yhteyksiä traditioon, toisiin teksteihin ja tekstien kerrostumiin. Ne ovat myös kommentoinnin kohde. Koodeina ne myös jäsentävät romaanin moninaista tematiikkaa. Venetsia ei ole Raittilalle ensisijaisesti maantieteellinen vaan kulttuurinen paikka, jossa risteävät paitsi taiteen ja kulttuurin myös kaupankäynnin, valtapolitiikan ja kansainvälisen rikollisuuden maailmat. Tähän viittaa sekin, ettei kirjailija ole pannut suurta painoa yksityiskohtien yhtäpitävyydelle todellisen Venetsian kanssa. Esimerkiksi hotelli Le Bains, jonka Raittila on sijoittanut Lidon laguunin puoleiselle rannalle, sijaitsee todellisuudessa meren puolella. Muissakin yksityiskohdissa on epätarkkuuksia.

Kuvaus ei ylipäätään perustu perinpohjaiseen Venetsiantuntemukseen. Raittila kertoo käyneensä Venetsiassa vuonna 1972 ja viettäneensä perillä kuusi tuntia, joten romaanin Venetsia perustuu ennen muuta "valehteluun, vaikutelman luomiseen" (Suojanen 2004). Romaanissa tämä idea ilmaistaan epäsuorasti Saraspään pohdinnoissa: "- taiteessa keinotekoinen on aina parempaa kuin oikea" (CG, 240). ${ }^{2}$

Henkilöhahmojen pohdinnat ja keskustelut taideteoksista liittyvät siihen, miten Venetsiaa on pidetty taiteen tyyssijana ja kuvausten kohteena: tämä tematisoi kaupungin keskeisyyden taide- ja kulttuurihistoriassa. Menneen jälkien havainnointi johtaa puheet myös kaupan ja sodankäynnin historiaan. Toisaalta Venetsia liitetään kirjoitusajankohtaan, nyky-Italiaan ja Euroopan unioniin. Venetsia edustaa ensisijaisesti koko eurooppalaista yhteiskuntaa, toissijaisesti sen eteläeurooppalaista (latinalaista, välimerellistä) versiota, johon suomalaisuus kontrastoituu.

Venetsian infrastruktuuri, rakenteet ja rakennukset sekä kulttuuri ovat syntyneet vuosisatoja sitten ja muotoutuneet vähitellen. Se on myös osa Italiaa, sen rikasta ja ikivanhaa kulttuuriperinnettä, johon suomalainen ja koko modernia arvostava pohjoismainen kulttuuri kontrastoituu. Marrasjärvi kiteyttää erot lahjomattomaan tapaansa:

Tipit ja lahjukset on korvattu pohjoismaisella sosiaaliturvalla, eläkerahastoilla ja työttömyyskassoilla. Näin toimii järkevällä tavalla järjestynyt yhteiskunta, joka on korvannut tulkinnanvaraisen etikettikäytännön selkeällä hinnoittelulla. Eurooppalaisilla on siihen vielä pitkä matka. Sitä pitempi, mitä kauempana asuvat Suomesta. (CG, 3I.)

Mikä tehtävä Venetsia-mytologialla romaanissa on? Venetsiasta puhuminen viittaa yhtä aikaa erilaisiin ja eriaikaisiin mytologisiin kerrostumiin. Romaania voikin luonnehtia uusmytologiseksi. Pekka Pesosen mukaan uusmytologinen teos on kirjallisuutta kirjallisuudesta, "poeettisesti

\footnotetext{
${ }^{2}$ Ajatus toistuu muuallakin Raittilan tuotannossa. Esimerkiksi Ei minulta mitään puutu romaanissa äänimies Panu pystyy loihtimaan katastrofin keskellä pidettävän suviseuratilaisuuden radiolähetykseen keinotekoisesti "ihmeellisen ai[don] tunnelma[n]”, mikä tuo vaikeassa tilanteessa oleville kuulijoille ”lohtua" (Raittila 1998, 246).
} 
tiedostettua leikkiä erilaisilla traditioilla, niiden luomilla hahmoilla ja tilanteilla, joista muodostuu tämän tradition hahmo" (1982, I58). Kaunokirjallisuuden mytologismissa ei ole kyse pelkästään myyttien käyttämisestä materiaalina vaan myös todellisuuden mytologisesta jäsentämisestä (Pesonen 1987, 103). ${ }^{3}$ Syntyvä todellisuuskuva on kerroksellinen, ja sitä luonnehtii joka suuntaan ulottuva viittausjärjestelmä:

Se [todellisuuskuva] on 'todellisuusvastainen', jos sen rinnalle asetetaan realismin maailmankuva, mutta se ei ole vain 'toista todellisuutta' kohti kurottuva, reaalitodellisuuden kieltävä leikki, vaikka esim. erilaiset symbolismin estetiikkaan kuuluvat teesit niin sanovatkin. (Pesonen 1987, I 16.)

Uusmytologinen teos on intertekstuaalinen, usein korostetusti: lukuisat alluusiot, sitaatit ja erilaiset mytologeemat käynnistävät vastaanottajassa monitasoisia assosiaatioita. Symbolistisen uusmytologisen tekstin erityispiirre on monilähtöisyys. Aihe ja hahmo ovat heterogeenisiä, mutta sisimmältään yhteenkuuluvia. Perimmältään ne ovat saman myytin variantteja. Kaupunki ja siihen liittyvä mytologia ovat tyypillisiä symbolistien käyttämiä perusmyyttejä, Pesonen sanoo ja käyttää esimerkkinä Andrei Belyin Peterburg-romaania (1916/1922), jossa jo teoksen nimi on koodi. Sitä täydennetään jatkuvasti erilaisilla viitteillä, jotka puolestaan toimivat koodeina. (Pesonen 199I, 48-49.)

Jo Canal Granden otsikko on koodi. Mytologisen kaupungin valtasuonena se viittaa Venetsiaan samalla tavoin kuin Nikolai Gogolin Nevan valtakatu (Nevskij Prospekt, 1835, suom. 1954) Pietariin. Muistomerkkien ja taideteosten lisäksi Canal Grandessa viitataan taidevirtauksiin kuten modernismiin, samoin talous-, sota- ja kirkkohistoriaan ja uskonnollisiin traditioihin. Kaikki nämä liittyvät toisiinsa ja mytologisoituvat romaanin aineksina.

Moniaineksisuus toteutuu paitsi alluusioina ja sitaatteina myös siinä, että samoja tapahtumia ja keskusteluja kerrotaan eri henkilöiden "äänillä” ja niin, että henkilöt siteeraavat muiden tulkintoja. Näin Venetsia ja kaikki, mitä se romaanissa edustaa, näyttäytyy lukijan kannalta yhtä aikaa rikkaana mutta myös haastavana: miten pelkistää keskeiset teemat ja tulkita mielekkäästi koko teosta jäsentävä näkemys?

\section{Kaupunki ja henkilöt sumussa}

Romaani alkaa lauseella: "Sumu jatkui kolmatta viikkoa" (CG, 7). Kertoja on insinööri Marrasjärvi ja hän kuvaa, miten suomalaisia kuljettava kone sukeltaa kirkkaasta auringonpaisteesta miltei läpitunkemattomaan sumuun, jonka keskellä he elävät ensimmäiset viikot. Hotellillekin he löytävät käsikopelolla, ja kaupungissa liikkuminen onnistuu Marrasjärveltä vain

\footnotetext{
${ }^{3}$ Mytologismi-termiä on käytetty erityisesti strukturalistisesti ja semioottisesti suuntautuneessa myytintutkimuksessa. Tarkastelun kohteena ovat kaunokirjallisuudessa eri tavoin ilmenevät myytit ja mytologiset lähtökohdat. (Pesonen 1997, 103; ks. myös Pesonen 1982 ja 1991.)
} 
navigaattorin avulla. Reilussa kahdessa viikossa Marrasjärvi näkee kaupungista vain katukiveystä, lohkeilevia tiiliseiniä ja koristeltuja raskaita jalopuuovia: "[en] ollut nähnyt yhtäkään Canal Granden varrella seisovista palatseista, joita meidän oli määrä ryhtyä pelastamaan” (CG, I4).

Kaupunki sumussa on kirjallinen topos, jota esimerkiksi Eino Leino käyttää allegorisessa runossaan "Helsinki sumussa" (1899). Siinä sumu peittää painostavana kaikki kaupungin keskeiset rakennukset ja kansalliset symbolit. Kansa astuu katuviertään parempaa toivoen ja toisilleen kuiskien, mutta "raudanraskaana" sumun keskeltä ilmestyy venäläinen sotilasosasto. (Leino 1931, 394-395.) Sumu symboloi venäläistä sortokomentoa, jota edustavat yhtäkkiä sumusta ilmestyvät ja sinne taas kätkeytyvät venäläissotilaat.

Leino ei ole ensimmäinen sumu-motiivin käyttäjä tapahtumanäyttämöä luodessaan. Jo Charles Dickensin Kolea talo -romaanissa (Bleak House, I852-53, suom. 2008) Lontoon kuvaus lähtee liikkeelle sumusta:

Sumua kaikkialla. Sumua yläjuoksulla, missä se liikkuu vihreiden saarien ja niittyjen lomassa, sumua alajuoksulla, missä se suttuisena vyöryy laivarivistöjen ja suuren (ja likaisen) kaupungin saastuneen rannan tienoilla. Sumua Essexin soilla, sumua Kentin kukkuloilla. (Dickens 2008, 9.)

Sumu vertautuu kaupungin yhteiskunnalliseen tilanteeseen: "Milloinkaan ei voi sumu olla niin sakea eikä kura ja rapa niin paksua, että se taivaan ja maan silmissä saisi aikaan mitään sellaista kuin kaikista piintyneistä synnintekijöistä siivottomimman, lordikanslerin oikeuden hoippuva törmäily" (mt., l0). Sumu, kura, jatkuva vesisade ja sakea yhteiskunnallinen epäoikeudenmukaisuus luovat yhdessä alakuloisen tunnelman romaanin alkukuviin.

Myös Canal Grandessa sumu toimii analogiana toisaalta Venetsian yhteiskunnalliselle ilmapiirille, toisaalta henkilöhahmojen mielentilalle. Suomalainen asiantuntijavaltuuskunta törmää byrokraattiseen sumurintamaan yrittäessään käynnistää avustusprojektiaan. Ensimmäisinä viikkoina he eivät saa paikallisilta viranomaisilta tarvittavia papereita tai toimitiloja käyttöönsä, joten he eivät pysty aloittamaan varsinaista työtään, jonka senkin sisältö jää epämääräiseksi, sumuiseksi. Sumua ja sen vaikutusta kommentoi myös Saraspää mutta hiukan eri näkökulmasta kuin Marrasjärvi:

Sumu jatkuu. En ole koskaan, edes tässä kaupungissa nähnyt tällaista sumua. Kävelen tuttuja kujia ja kanavanrantoja pitkin aivan pöhköpäisenä. Tuossa tulee sumuhöyrystä esiin tuttu sillankaide, tuossa taas palatsin ovipielen pronssiveistos - - välillä kadoten, välillä ilmaantuen niin, että hetken päästä epäilet oliko näkemäsi peräisin tästä maailmasta vai oman mielesi piiloista. (CG, I3.)

Sumun takia henkilöt ikään kuin leijuvat vailla kiinnekohtaa mihinkään lujaan ja totuttuun: he hapuilevat epäselvässä tilanteessa labyrinttimaisessa kaupungissa kiintopisteitä etsien melkein kuin Franz Kafkan Oikeusjutun (Der Prozeß, 1925, suom. 1986) päähenkilö. He saattavat myös epäillä omia havaintojaan: ovatko ne peräisin todellisesta maailmasta vai oman mielen syvyyksistä? Sumu sekoittaa, painostaa ja lannistaa, se eristää, 
peittää ja hämää mutta toisaalta se myös pelkistää ja pakottaa katsomaan lähelle. Jotkut romaanin henkilöistä päätyvät pohtimaan omaa sisintään, omia motiivejaan ja sitä, mikä itselle maailmassa lopulta on tärkeää.

Sumu myös verhoaa, toimii ikään kuin naamiona - maailma näyttää sumussa aivan erilaiselta kuin auringonpaisteessa. Tapahtumapaikka näyttäytyy suomalaisryhmälle auringonpaisteessa vasta lähes kolmen viikon kuluttua siitä, kun he ovat Venetsiaan saapuneet. Silloin kaupunki ikään kuin riisuu sumunaamionsa. Naamioituminen liittyy myös henkilöihin ja tarinan tapahtumiin: "Talvi"-jakso huipentuu Venetsian karnevaaliin, johon naamiot ja identiteettien vaihdokset liittyvät aivan konkreettisesti.

Realismille ominaisista hahmoista poiketen Raittilan henkilöt ovat tyyliteltyjä ja kirjalliseen traditioon viittaavia. Pohjalla on jokin stereotypia: näin toimii suomalainen insinööri, tällä tavalla katsoo maailmaa akateemisessa umpiossa elänyt tutkija, tältä kuulostaa nuori itsenäinen nainen. Romaani itse tarjoaa tulkintamallin omista henkilöistään: "Heikkilän mukaan me itsekin olimme yllättävän pitkälle pelkkiä luonnenaamioita ja tyyppejä emmekä mitään moniulotteisia ja täyteläisiä henkilöitä” (CG, 283). Dosentin luonnehdinta käy lukuohjeeksi romaanille, siinä pelataan stereotyyppisillä vastakohdilla: insinööri - humanisti, vanheneva (kuoleva) mies - nuori vitaalinen (hedelmällinen) nainen, pohjoismainen - etelämaalainen, suora toiminta - byrokraattinen (tietoinen) hidastelu.

Dosentti Heikkilä stereotyyppisenä yliopistomiehenä ei tyydy pelkästään viittaamaan fiktiivisten tekstien erilaisiin henkilöhahmoihin ja luonnenaamioihin vaan pitää jopa pienimuotoisen luennon aiheesta Commedia dell'arte, joka on tärkeä juonne paitsi eurooppalaisessa teatteriperinteessä myös karnevaalissa:

\section{Heikkilä kertoi, että naamiot, asut ja henkilöt, joita niiden avulla esitet- tiin olivat klassisia karnevaalihahmoja. Perushenkilöt tulivat ilveilyperin- teestä, Commedia dell' artesta. Se oli ollut rahvaan katuteatterin vallit- seva muoto tuhatseitsemänsataaluvulle asti. (CG, 246.)}

Ilveily- ja karnevaaliperinteen esittelyn voi tulkita kertomustason materiaaliksi, romaanin näyttämöksi ja lavasteeksi, Venetsia-rihkamaksikin. Mutta muistaen Canal Granden uusmytologisen luonteen romaanin "perushenkilöitä" kannattaa tarkastella commedia dell'arte -perinteen valossa, koska romaanin tietoviisas dosentti siihen suoraan viittaa. Mihail Bahtinin mukaan commedia dell'arte juontaa juurensa torien naurukulttuurista $(2002,33) .{ }^{4}$ Sen hahmot ovat aikojen saatossa varioineet, ja nimetkin ovat vaihdelleet.

Vakiohahmoina on useimmin kaksi vanhempaa miestä, kaksi nuorempaa miespalvelijaa, rakastavaiset ja palvelustyttö. Keskeinen on Pantalone, rikas aatelinen tai kauppias, joka haluaa naittaa tyttärensä tai mennä itse naimisiin. Tärkeä on myös // Dottore, aina oppinut ja

\footnotetext{
${ }^{4}$ Improvisoiduista näyttämötilanteista versonut kansankomedia kehittyi omaksi lajikseen Italiassa I400-luvulla ja eli loistokauttaan I500-luvun puolivälistä I700-luvulle. Sen hahmot edustavat erilaisia yhteiskuntaluokkia, ammattikuntia ja asuinpaikkoja. (McKee 1989, XIII-XX; Rudlin 1994, I3-33, 57-58.)
} 
kaikkitietävä, mitä ilmentää suuri määrä puhetta ja esitelmöintiä. ${ }^{5}$ Naispuolisen palvelijan nimeksi vakiintui Colombina, joskin muitakin nimiä on esiintynyt. I/ Capitano puolestaan on kerskaileva upseeri, joka yrittää turhaan tehdä vaikutuksen naisiin. ${ }^{6}$ Tarkastelen seuraavaksi romaanin keskeisiä henkilöhahmoja ja niihin kytkeytyvää tematiikkaa dosentti Heikkilän tarjoaman koodin avulla.

\section{Historia - nykypäivä}

II Dottore -hahmoja on romaanissa kaksikin, Heikkilä ja Saraspää (jälkimmäiseen palaan tuonnempana). Dosentti Heikkilä tietää kaiken historiasta, taiteesta ja teologiasta, mutta nykyhetken ongelmat ovat hänelle pelkkiä sytykkeitä loputtomiin luentoihin ja oman oppineisuuden esittelyyn. Hän on lisäksi omasta tyypistään tietoinen: "Hän [Heikkilä] tietysti olisi itseoikeutettu II Dottore, huvittava oppinut, joka sönköttää omatekoista latinaa, luennoi loputtomia rikkiviisauksia ja on tietävinään kaikesta kaiken, vaikka ei oikeasti tiedä mistään mitään” (CG, 282).

Heikkilä-hahmo on sekä rakenteen että tematiikan kannalta tärkeä, vaikka hänen puheensa ja toimintansa suodattuukin tarinaan Marrasjärven, Saraspään ja Tuulin kautta. Hahmo perustuu pitkälle romaaniperinteelle: hän on toiminnallisen aisaparinsa Marrasjärven epäitsenäinen, epäkäytännöllinen mutta puhelias osapuoli. Saraspää näkeekin heidät "Manzan ritarina ja hänen aseenkantajanaan” ja mykkäfilmistä tunnettuina Majakkana ja Perävaununa. Don Quijoteen ja Sancho Panzaan verrattuna Marrasjärven ja Heikkilän roolitus on kuitenkin käänteinen. Heikkilä on kirjanoppinut ja lukutoukka, Marrasjärvi käytännön mies, jonka taistelu tuulimyllyjen kanssa on taistelua italialaista byrokratiaa ja eteläeurooppalaista saamattomuutta vastaan.

Heikkilän historiatietämys luo ironista vastavaloa Marrasjärven askaretason ajattelulle, joka konkretisoituu täydellisenä tietämättömyytenä tapahtumaympäristön kulttuuriperinnöstä: "Heikkilä selitti hakevansa [kartalta] Vergiliuksen ja Catulluksen huviloiden paikkoja. Dosentin italialaiset ystävät tuntuivat olevan varakasta väkeä. Se etsi huviloita Gardajärven rannoilta eikä tonttimaa siellä voinut olla halpaa” (CG, 218). Saraspää taas ironisoi Heikkilää siitä, että tällä menevät sekaisin historia ja tämän hetken todellisuus: "Tuntuu kuin Heikkilä ottaisi kaiken irti siitä, että pääsee elämään todeksi sen mitä on historioitsijana lukenut varhaisrenessanssin kaupunkivaltioiden juonitteluista" (CG, I42).

Heikkilän oppineisuus ei kuitenkaan ole pelkkä komiikkaa tuottava piirre. Heikkilä esimerkiksi hahmottelee vaivattomasti yhtymäkohtia menneen ajan ja nykyajan maailmanvaltojen välillä: "- Venetsia oli

${ }^{5}$ Tarkemmin: Nicoll 1963, 44-60; Rudlin 1994, 9I-102; McKee 1989, XV.

${ }^{6}$ Hahmossa on kaikuja paitsi Don Juanista myös Don Quijotesta (Rudlin 1994, 121). Nuorten rakastavaisten (innamorati) rooli ei ole keskeisimpiä, mutta näytelmä usein päättyy siihen, että he saavat toisensa. Miespalvelijat eli zannit ovat yleensä ilveilijöitä, ja he tekevät akrobaattisia temppuja ja puhuvat törkeyksiä. Nimiä ovat esimerkiksi Arlecchino, Brighella, Pulcinella ja Scapino. (Nicoll 1963, 95-I I2; Rudlin 1994, I06-I30.) 
strategiselta asemaltaan ja sotilasopiltaan täsmälleen kuin meidän aikamme Yhdysvallat!” (CG, 84). Rinnastus on tärkeä: häikäilemätön kaupankäynti, kuljetusreittien turvaaminen sekä muiden riistäminen oman hyvinvoinnin ja turvallisuuden nimissä tulevat toistuvasti tarinassa esiin. Heikkilän puheet byrokratian synnystä, Max Weberistä ja paralleeliaktiosta ovat nekin temaattisesti tärkeitä, eivät pelkkää oman oppineisuuden osoittamista. ${ }^{7}$

\section{Kansalliset stereotypiat}

Canal Granden selvin Pantalone-hahmo on insinööri Marrasjärvi. Se tiedostetaan myös romaanin maailmassa: "Dosentti keksi, että olen ilmiselvä Pantalone, äreä vanhempi mies, joka myös sai kaiken aikaa olla huolissaan tyttärestään, mutta kurkki itse kuitenkin salaa nuorten tyttöjen hameitten alle" (CG, 282). Marrasjärvi ei kurki naisten hameiden alle mutta on kireähkö keski-ikäinen mies, jolle maailma on käytännöllisten päätösten ja konkreettisten toimenpiteiden kenttä. Kaikille esteettisille, historiallisille ja kulttuurisille arvoille sokeana hän on huolissaan nimenomaan projektin etenemisestä ja Venetsian kunnosta. Hän laskee kustannuksia, hämmästelee italialaisten epäkäytännöllisyyttä ja vaatii nopeita ja radikaaleja ratkaisuja:

Ilmoitin, että minut oli opetettu varautumaan aina pahimpaan. Sen laiminlyönti olisi vastoin koulutusta ja ammattimoraalia. Olin tullut Venetsiaan nimenomaan luomaan periaatteet, joita noudattamalla venetsialaiset voisivat itse pitää kaupunkinsa veden pinnalla kaikissa olosuhteissa. (CG, 86.)

Marrasjärvi ottaa tehtävänsä äärimmäisen vastuullisesti ja vakavasti, mikä näyttää italialaisessa ympäristössä huvittavalta suuruudenhulluudelta. Heikkilä kutsuukin häntä "San Salvatoreksi”, mutta Marrasjärvi ei ironiaa ymmärrä. "Varautuminen on avainsana!", hän kuuluttaa ikään kuin oman toimintansa mottona. Hän ei käsitä eteläeurooppalaisten tapaa mukautua vallitseviin olosuhteisiin: hehän varautuvat talveenkin vain kaulaliinoin, sormikkain ja tilapäislämmittimin eivätkä tilkitse talojaan (CG, I39).

Marrasjärvessä on myös II Capitano -tyypin piirteitä: hänessä on nimittäin annos Don Quijotea, joka on yksi II Capitanon protohahmoista. Se parodioi muun ohessa sotilasta, ja Marrasjärvi on kuin onkin saanut sotilaskoulutuksen ja esimerkiksi hiihtänyt laskuvarjojääkärikillan

\footnotetext{
${ }^{7}$ Muissakin Raittilan teoksissa esiintyy samanlaisia esitelmöitsijöitä kuin dosentti Heikkilä. He tuovat romaaneihin tiedollisen, joskus jopa ensyklopedisen aspektin. Esimerkiksi Ei minulta mitään puutu -romaanissa (1998) tällainen hahmo on uskontotieteilijä Leila Mustamäki, Atlantiksessa (2003) it-miljonääri Saarilahti. Terminaali-romaanissa (2013) tietoa esimerkiksi globalisoituvasta yhteiskunnasta, löytöretkistä, lentoliikenteestä, rajavalvonnasta, purjehtimisesta, kansainvälisestä terrorismista, tyttöjen alakulttuurista ja valkoposkihanhikantojen runsastumisesta välittävät useammatkin eri henkilöhahmot, ja romaanin jotkut luvut ovat eräänlaisia tietoiskuja aina uudesta aihepiiristä. Lukija ei tietenkään voi lukiessaan olla varma, onko romaanin välittämä tieto "oikeaa" vai onko se fiktiivistä, romaanin tarpeisiin luotua tai modifioitua.
} 
retkikunnan mukana Grönlannin poikki. Hänessä on upseerimaista suoraviivaisuutta, valmiutta vastuunottoon eli juuri niitä ominaisuuksia, jotka Raittila on toisaalla määritellyt suomalaisen johtajuuden malliksi. Sitä leimaa vuorovaikutuksen sijasta "mykkä vastuunotto": "Johtajan tärkeimpiä ominaisuuksia ovat perinteiset upseerihyveet: paineensietokyky, häikäilemättömyys ja kirkas tieto tavoitteesta. Salaamiskäytäntö on itsestään selvä osa ohjesääntöä" (Raittila 2002, 96).

Marrasjärven voi tulkita myös suomalaisen jokamiehen karikatyyriksi. Romaani itsekin viittaa tähän. Saraspään mukaan insinööri Marrasjärvi on "tyylipuhdas hahmo", joka kuolisi Tanskan salmien eteläpuolella yksin jätettynä nälkään, koska ei osaa käyttää "hyvän käytöksen kaapuun kätkettyjä teräviä kyynärpäitään" eikä hinnoitella hymyään:

Suomalainen mies on todellakin kuten viimeinen mammutti, joka yrittää elää sulavan jään reunalla ja tulla raivokkaasti toimeen vieraaksi käyvässä maailmassa, Euroopan urbaanissa juonitteluympäristössä, jossa ei tunneta sellaisia perisuomalaisia ajatustapoja kuten: "...veihän naapurimme touon halla", "Kaveria ei jätetä!” tai ”Jokainen ihminen on laulun arvoinen." "Korpes raivio, kultavainio" - sieltä suomalaisen miehen ei olisi koskaan pitänyt joutua pois. (CG, 143-144.)

Arjen elämänviisauksiksi kiteytyneet sanonnat ja sitaatit näyttäytyvät välimerellisessä ympäristössä huvittavilta kliseiltä. Saraspään ironiset lausahdukset edustavat suomalaisuuden kuvastoa kuluneimmillaan, mikä korostaa Marrasjärvi-hahmon stereotyyppisyyttä. Marrasjärvi kertoo tapahtumista kronologisessa järjestyksessä toimenpiteitä kuvailemalla ja muiden puheita raportoimalla. Mukana on yksityiskohtaista työnkuvausta, tarvikkeiden luetteloita ja viittauksia teknisiin toimenpiteisiin:

Dosentilla oli reppu, johon olimme pakanneet siivikot sekä neljän tuu-
man laudasta valmistamani asteikot vesipinnan korkeusvaihteluiden
mittaamiseksi. Omassa rinkassani oli vasara ja nauloja, akkuporakone,
saha, nippusiteitä ja pari vyyhtiä köyttä. Olimme kalibroineet siivikko-
mittarit vetämällä laitetta vakionopeudella kylpyammeessa ja laskemalla
potkuriakselin kierrokset. (CG, 25.)

Marrasjärvi kirjaa tapahtumia ja asiantiloja, esittää välilä jyrkkiäkin näkökantoja, mutta ei ilmaise omia tunteitaan eikä harrasta minkäänlaista psykologisointia - hän on toimija, tekijä, läpikotaisin käytännöllinen ja asiakeskeinen. Marrasjärvi-osuuksia voi kutsua insinööriproosaksi, myös sillä tyylittelyksi ja parodiaksikin, jos pitää Marrasjärveä pelkästään koomisena hahmona.

Raittila on eritellyt insinööriproosaa toisessa yhteydessä (2002, 56-57). ${ }^{8}$ Hänen mukaansa oikeaa insinööriproosaa eivät kirjoita insinöörit (vaikka käyttääkin esimerkkeinä juuri diplomi-insinöörien, Antti Hyryn ja Antti Tuurin tekstejä) eikä niiden kuvausten perusteella kannata pystytellä voimalaitoksia tai rakentaa kulkuneuvoja, koska kysymys on runoudesta: "Todellinen insinööriproosa suhtautuu tekniikkaan kuin Don Quijote ritariromaaniin. Energiaa ladatakseen insinööriproosa jännittää

\footnotetext{
${ }^{8}$ Yleiseen käyttöön jääneen insinööriproosa-termin keksijää en tiedä, mutta Raittila lienee ensimmäinen, joka sitä on eritellyt edes yhden kolumnin verran.
} 
itsensä kylmän modernismin ja kuuman romantiikan väliin taiteilemaan.” Laji on miehinen, koska se on pintansa alla niin herkkää ja sentimentaalista ja koska sen tekijät ovat Hemingwayn kaltaisia piilonyyhkyjä, Raittila (mp.) väittää.

Vaikka Marrasjärvi on yksivakainen insinööri ja keski-ikäinen perheenisä, jota Tuuli, nykyajan nuori nainen, pitää pelkkänä torvelona, hän tuottaa kuitenkin sellaista proosaa, jossa "lataus syntyy suuren tunteen ja sen kätkemisen välisestä jännitteestä" (Raittila 2002, 56-57). Eikä tässä vielä kaikki: Raittila panee insinöörinsä keksimään modernismin perusidean:

\begin{abstract}
En ollut ajatellut koskaan asiaa, mutta nyt mietin, että tarkoituksenmukaiset ja pelkistetyt esineet olivat oikeastaan aina myös mukavan näköisiä. Taloista, esineistä, jopa lauseista ja sanoista pitää karsia pois tarpeeton. Niiden täytyisi olla selkeitä, kirkkaita niin, että tarkoitus näkyy jo ulkoasussa. Muodossa saa olla vain se, mikä on sisällön kannalta välttämätöntä. (CG, 40.)
\end{abstract}

Muotoilut ovat suoraan suomalaista modernismia käsittelevistä esityksistä, joissa vilahtelevat sellaiset käsitteet kuin tarkoituksenmukaisuus, täsmällisyys, eleettömyys, asiallisuus, kirkkaus, arkisuus, puhtaus, luontevuus, pakottomuus ja luonnollisuus. ${ }^{9}$ Insinööri havaitsee senkin, että sekä aineellisen (talot, esineet) että aineettoman (lauseet, sanat) tarkoituksen tulee olla kirkas, pelkistetty. Canal Grandessa puhe modernismista koskee paitsi kirjallisuutta myös muotoilua ja arkkitehtuuria, joiden osalta Venetsia edustaa vanhaa ja Suomi uutta ajattelua. Kaikkineen Marrasjärvi henkilöi suomalaista modernismia, jonka vastakohtana toimii venetsialainen ja ylipäätään välimerellinen perinne koristeellisuuksineen ja epäkäytännöllisyyksineen.

\title{
Kuolema Venetsiassa
}

Toinen tarinan II Dottore -hahmo on Saraspää. Minäkertojana hänestä muotoutuu selvästi Heikkilää monisyisempi. Karnevaalissa Saraspää omaksuu itse II Dottore -roolin pukeutumalla mustaan tohtorinviittaan, kolmikolkkahattuun ja pitkänokkaiseen ruttotohtorin maskiin:

Minä en ole mikään naurettava Pantalone tai kapteeni enkä rähisevä palvelija. Minä olen ruttotohtori, kunnioitettu ja pelätty. Ja nenä minulla on hävyttömän pitkä. Valitettavasti se on mennyt poikki. Mutta minulla on toinen naamari. (CG, 286.)

"Toinen naamari" on aivan konkreettinen esine, Yhdysvaltain armeijalta varastettu pimeänäkölaite, jonka Saraspää saa käsiinsä ja jota hän käyttää karnevaalissa. Sen avulla hän myös löytää Balkanilta salakuljetetun ikonin, johon hän viimeisinä päivinään turvautuu. Romaanin kompositiossa "toinen naamari" on tulkittavissa esittämisen ja minäkuvan muokkaamisen ironisoinniksi. Saraspään alkuperäinen nimi on Snellman, mutta hän on vaihtanut sen suomenkieliseksi. Romaani vitsailee näin sillä, miten

${ }^{9}$ Ks. esim. Laitinen 1958, Tarkka 1980, Viikari 1992, Hökkä 1999. 
kirjailija Anja Kauranen ja toimittaja Saska Saarikoski ottivat itselleen yhteisen sukunimen, Saarikosken sukutaustasta löytyneen Snellmanin. Romaanin maailmassa Saraspään entinen nimi liittää hänet kulttuuriasiainneuvos Snellin tavoin myös fennomaniaan ja kansalliseen ikonografiaan, josta Saraspää itse on kuitenkin halunnut irtaantua nimenvaihdoksen kautta eli "toisen naamarin" avulla.

Naamarit ja nimien vaihdokset liittyvät identiteettien ja roolien häilyväisyyteen; karnevaalissahan näyttelijöiden ja yleisön välillä ei ole selvää rajaa. Pimeänäkölaitteen käyttö symboloi myös yleistä pimeyttä, sokeat ja sokeiden taluttajat menevät sekaisin ja lankeavat raamatullisen kuopan sijasta sen venetsialaiseen vastineeseen: Snellmannin / Saraspään / ruttotohtorin ruumis löydetään kanavasta.

Canal Grande tematisoi yhteiskunnallisia ja eettisiä ongelmia. Bahtinin mukaan commedia dell'arte -perinteessä ilmenevällä karnevalistisgroteskilla muodolla on selvä päämäärä:

- - se pyhittää kuvitellun vapauden, antaa mahdollisuuden koota yh-
teen erilaatuista ja lähentää toisilleen vierasta, auttaa vapautumaan hal-
litsevasta näkökulmasta maailmaan, kaikesta konventionaalisesta, ylei-
sesti tunnetuista totuuksista, kaikesta tavanomaisesta, totutusta, tun-
temaan kaiken olemassaolevan suhteellisuuden ja aivan toisen maail-
manjärjestyksen mahdollisuuden. (Bahtin 2002,33 .)

Canal Grande kokoaa yhteen hyvin erilaatuisia aineksia. Samalla se kyseenalaistaa karnevalisoinnin keinoin yleisiä totuuksia ja tavanomaisuuksia. Näin se ikään kuin kyselee "aivan toisen maailmanjärjestyksen mahdollisuutta" henkilöhahmojensa suulla - ennen kaikkea Tuulin kertomuksessa, johon romaani huipentuu.

Myös Saraspään kerronnassa toisen maailmanjärjestyksen mahdollisuus tematisoituu, sillä hänen osakseen jää väistyä uuden tieltä. Saraspään "perintö" kuitenkin jää elämään uudessa maailmassa uudessa muodossa: Tuulin odottama lapsi saattaa olla Saraspään, vaikka tämä mahdollisuus jääkin avoimeksi. Saraspään päiväkirja joka tapauksessa jää Tuulille, samoin ikoni, jonka Saraspää evakuoi italialaispoikien salakuljetusvarastosta ja josta hän viimeisinä elinpäivinään etsii lohtua ja turvaa. Siinä missä Marrasjärvi edustaa suomalaisuutta ja käytännöllistä modernismia, Saraspää edustaa eurooppalaista hengenelämää, sitä elähtänyttä modernismia, jonka aika on jo ohi - niin Marrasjärven kuin Tuulinkin näkökulmasta.

Saraspää on kerronnassaan Marrasjärveä pohdiskelevampi. Kyse on päiväkirjasta: jaksot on otsikoitu päivämäärin ja kuvaukset koskevat pääosin päiväkohtaisia tapahtumia. Merkinnät sisältävät oman terveydentilan tarkkailua, kriittisiä arvioita muista henkilöistä sekä kulttuurisfilosofisia vuodatuksia. Saraspää ei tyydy pelkkään kuvaukseen, vaan pohtii henkilöiden motiiveja, tekee rinnastuksia eri kulttuurien välilä sekä viittaa kirjallisuuteen ja taiteeseen. Hän erittelee myös omia pelkojaan ja aikomuksiaan: "On selvää, että alan kohta harjoittaa vanhaa pahettani" (CG, 42).

Tempuksena on pääosin preesens, mikä luo tekstiin välittömyyden ja ennakoimattomuuden tunnun. Kertoja ei voi tietää, miten päiväkirjamerkinnöistä rakentuva kertomus tulee jatkumaan ja miten se 
lopulta päättyy. Loppupuolella Saraspään merkinnät muuttuvat hajanaisiksi, jopa tajunnanvirtamaisiksi, kunnes loppuvat kokonaan. Saraspään esitystapa on paitsi kaunokirjallista myös itsestään tietoista: "Tämä on täsmällinen ja konkreettinen kuvaus siitä, mitä tapahtui” (CG, 278).

Saraspää-nimen voi tulkita edustavan uuden ja vanhan ristiriitaa. Uuden päivän sarastukseen yhdistyy jonkin asian päättyminen, (tien)pää. Saraspää on edustanut nykyaikaa, uutta ajattelua ja eurooppalaista hengenelämää, mutta hänen aikakautensa on tullut nyt päätökseen. Tässä hän rinnastuu Thomas Mannin Kuolema Venetsiassa -pienoisromaanin päähenkilöön, Gustaf Aschenbachiin, josta dosentti Heikkilä Lidolla Marrasjärvelle luennoi. Heikkilä nimeää Aschenbachin mennyttä Eurooppaa edustaneeksi kirjailijaksi, "jonka Mann oli luonut voidakseen antaa hänen kuolla pois aikansa mukana" (CG, 47). Saraspää ja Aschenbach tajuavat kaupungin ja sitä kautta eurooppalaisen sivilisaation sairauden, mutta kummallakaan ei ole voimaa ponnistaa siitä eroon vaan he ikään kuin katsovat taakseen Lootin vaimon tavoin kuollakseen kaupungissa sen rappion symbolisesti jakaen.

Hemingwayn Joen yli puiden siimekseen -romaanin päähenkilö eversti Cantwell kuuluu samaan Venetsiassa kuolevien menneen ajan edustajien sarjaan. Hänenkin viimeinen käyntinsä kaupungissa on hyvästijättöä ja myös hän saa kokea eroottisen intohimon lyhyen leimahduksen, kuten Mannin Aschenbach. Romaani mainitaan Canal Grandessa ikään kuin ohimennen, kun Saraspää kirjoittaa: ${ }^{10}$

Ajatus sorsajahdista Venetsian vesillä johtaa meidät puhumaan Hemingwayn romaanista Joen yli puiden siimekseen. Keskustelu aiheesta loppuu lyhyeen, kun ilmoitan, että kirja on mielestäni vastenmielinen. (CG, 62.)

Cantwellin tavoin Saraspää kokee kiihkeän eroottisen tuokion nuoren naisen kanssa, kun hänen onnistuu taivutella Tuuli sänkyyn kanssaan ("anna edes säälistä, sairaalle miehelle", kuten Tuuli tilanteen tulkitsee), ja viagran ja beta-salpaajien voimalla hän toteuttaa pakkomielteensä menehtyäkseen sen jälkeen sydänkohtaukseen. Tuuli on hänen Tadzionsa ja Renatansa, ja kuten Aschenbachin ja Cantwellin, myös Saraspään viimeinen ihastus on nuori, elinvoimainen ja jo uuteen aikakauteen kuuluva. Vanhan maailman, väsähtäneen ideologian ja rappeutuvan kulttuurin edustajien on määrä kuolla juuri Venetsiassa, johon ovat kerrostuneet kaikki menneen maailmanajan jäljet. ${ }^{11}$

\footnotetext{
${ }^{10}$ Raittilan Marsalkka-romaanissa (2010) Martha Gellhorn viittaa romaanin syntyyn ja keskeiseen teemaan: "Ernest väitti kirjoittavansa romaania, jossa amerikkalainen kenraalista alennettu eversti kohtaa elämänsä viimeisen ja suurimman rakkauden Venetsiassa. - - 'Elämänsä viimeinen ja suuri rakkaus'... Kuulostaa pahalta! Kirjan nimeksi on tulossa Joen yli puiden siimekseen. Ernestin kirjojen nimet ovat muuttuneet oudoksi romanttiseksi botaniikaksi." (Raittila 2010, 243-244.)

${ }^{11}$ Raittilan romaanissa on muitakin yhtymäkohtia Hemingwayn romaaniin, kuten lintujen metsästäminen laguunin kaislikossa ja käynnit Harryn baarissa. Raittilalla tosin metsästys osoittautuu pelkäksi hämärien liiketoimien rekvisiitaksi: italialaiset käyttävät suomalaisia asiantuntijoita rikollisten puuhiensa naamiointiverkkona.
} 
Karnevaalihumu ja lääkehumalan kiihottamat pakkomielteet riivaavat Saraspäätä, jonka tietoisuus sulaa yhteen suurten taideteosten, raamatullisten kuvien ja myös esteettisten prinsiippien kanssa:

Minä näen ehkä asioita, joita muut eivät näe, mutta minä pystyn yhä kirjoittamaan. - - Ylläni on ruttotohtorin pitkänenäinen naamari ja musta viittaa. Viittani alla, sinä joka luet tämän, viittani alla on Jumalanäiti. Tämä ei ole mikään metafora. Viittani alla on Jumalanäiti, Jumalanäidin kuolonuni. - -

Pidän mieleni kirkkaana, vaikka kuulen suuren kuoron laulavan Mozartin rekviemiä ja nousen tämän pienen kahvilan kattoon kuin ilmapallo. - - Ei vertauksia. Eikä huutomerkkejä. Ei selityksiä, ei kommentteja eikä varsinkaan vertauksia. Kovaa, kylmää kuvausta ja kerrontaa, ei muuta. - - Minä nostan silmäni vuoria kohti ... ei pidä luulla, että täällä olisi vuoria. Mutta minulla on Raamattu. Mistä tulee minulle apu?

Minulla on Jumalanäiti, Harlekiinin paketti ja Raamattu. (CG, 278.)

Apua ei tule vuorilta, lääkkeistä, Raamatusta, Jumalanäidistä, roolien vaihdoista eikä edes nuoresta ihastuksesta. Saraspää sortuu ja vajoaa niin kuin Venetsia, jonka pelastaminen ei häntä jaksa kiinnostaa. Hänen aktiivisuutensa riittää enää omien halujen tyydyttämiseen. Toisaalta: epätoivoinen takertuminen Tuuliin, halu rakastella tämän kanssa vaikka viimeisillä voimilla, voi olla myös uhmaa kuoleman edessä.

Saraspään esteettis-apokalyptiset houreet voi tulkita paitsi lääketokkuran oireiksi myös nykyaikaistetuiksi versioiksi Aschenbachin viimeisten päivien mietteistä. Samalla ne kuitenkin rakentavat teoksen yhteiskuntakriittistä tasoa. Karnevalistisen kuoren alla on julma todellisuus, jossa inmisetkin ovat kauppatavaraa samaan tapaan kuin Ilmestyskirjan Suuressa Babylonissa, johon Saraspää omassa kertomuksessaan implisiittisesti viittaa.

\section{Sumusta aurinkoon}

Tuulin kerronta poikkeaa jyrkästi sekä Saraspään että Marrasjärven kerronnasta. Se on suoraa ja sumeilematonta nuoren ihmisen puhekieltä: "Jos Miriam tyhjentää mun tilin, mä olen kusessa." 12 Teksti on ikään kuin kevyesti editoitua suullista esitystä, joka luo vastakohdan sekä Saraspään essee- ja päiväkirjatyylille että Marrasjärven insinööriproosalle, joka asiallisuudessaan on varsin kirjallista.

Tuulin hahmo rakentuu pitkälti vasta Kevät-jakson mittaan, jossa hän paljastuu tarinan ainoaksi positiiviseksi sankariksi. Kevät-jakso kerrotaan ikään kuin parilta kolmelta istumalta, kun on kulunut kolme kuukautta Talvi-tarinan lopusta, Marrasjärven Suomeen paluusta ja Saraspään kuolemasta. Kerrontahetkellä Tuuli on raskaana ja töissä ranskalaisella viinitilalla. Hän lukee haltuunsa jääneet Saraspään päiväkirjat ja löytää Marseillen merimieskirkolla käydessään suomalaisesta lehdestä

\footnotetext{
${ }^{12}$ Samantapaista on Ei minulta mitään puutu -romaanin äänimiehen Panun kerronta: "Ei jumalauta, mä kelasin, missä mä oikeen olen?” (Raittila 1998, 27).
} 
tiedon, että Saraspään ruumis on löydetty. Lapsen ensimmäiset liikahdukset herättävät kysymykset: kuka onkaan lapsen isä, miten kaikki oikeasti tapahtui ja miten tästä eteenpäin? Tuulin kertomus on pääosin sen purkamista, mitä hän Venetsiassa koki ja miksi hän kaupungista lähti. ${ }^{13}$

Tuuli edustaa Raittilan keskeistä tyyppihahmoa, josta kehittyy uusien teosten myötä myös eri variaatioita. Raittilan varhaisessa novellissa "Caribaldino Finlandese" (1994) esitellään jo commedia dell'arte -hahmot, ja myös siinä esiintyy Tuuli-niminen nuori viehättävä nainen. Novellin tarina sijoittuu Roomaan ja Tivolin kaupunkiin, ja sen henkilökertoja on Marrasjärven oloinen insinööri. Lisäksi tarinassa seikkailevat historian dosentti, suomalainen sirkustaiteilija, suomalainen kirjailija, Villa Lanten johtajatar sekä apulaistyttö Tuuli. Canal Granden henkilögalleria ei siis juuri poikkea novellin vastaavasta. ${ }^{14}$ On huomattava, että novellin Tuuli nimetään Columbine-hahmoksi, joka on "kaikkien miesten tunteiden kohteena, ihana nuori neito" (Raittila 1994, 34). ${ }^{15}$ Myös Canal Granden Tuuli on Columbine-hahmo, mutta romaanissa tällä hahmolla on toisenlainen funktio kuin novellissa: hän ei jää pelkäksi ihanaksi nuoreksi neidoksi, miesten tunteiden passiiviseksi kohteeksi, vaan osoittautuu aktiiviseksi toimijaksi, lopulta sankariksikin.

Marseillessa Tuuli puhuu piinallisesta tilanteestaan suomalaiselle merimiespapille, ja samalla selviää, että hän on pelastanut moldovalaisen ihmiskaupan uhriksi joutuneen tytön, jonka on määrä lähettăä mafialle kuukausittain rahaa; panttina on tytön pikkuveli. Tuuli on antanut hänelle oman pankkikorttinsa ja toimittanut pois Italiasta. Mafialle lähetetyt rahat ovat hänen perintörahojaan, jotka hupenevat kuukausi kuukaudelta, koska Tuuli ei halua moldovalaistytön myyvän itseään, kuten mafia edellyttää. Keskustelussa papin kanssa Tuulin järjestelyt saavat laajat ja syvät ulottuvuudet:

${ }^{13}$ Romaanin sivuhenkilöt, zannit, tulevat suomalaisille tutuiksi Tuulin kautta. Paikalliset nuoret miehet Carlo ja Ettore ovat tekemisissä salakuljetuksen ja harmaan talouden kanssa. Heidän kauttaan peilataan italialaista yhteiskuntaa ja toimintakulttuuria. Amerikkalaislentäjä Mike ja elokuvaohjaaja George edustavat romaanissa Amerikkaa, globaalitaloutta säätelevää maailmanmahtia, menneen ajan Venetsian nykyversiota, ja George myös amerikkalaista populaarikulttuuria. Mike edustaa lisäksi väkivaltaa ja järjestäytynyttä kansainvälistä rikollisuutta, huumebisnestä ja ihmiskauppaa. Hänet voi tulkita myös II Capitano -hahmoksi, joka häpeäkseen häviää pistooliammuntakisan II Capitano Marrasjärvelle (CG, 55-60). Humalaisten pistooliammuntakilpailu Lidon hiekkarannalla on kirjallinen silmänisku, viittaus Antti Tuurin Pohjanmaahan (1982), jossa ammuskellaan Suomi-konepistoolilla Lummukan hiekkakuopilla.

${ }^{14}$ Novellinkin dosentti esittelee commedia dell'arte -perinnettä ja vertailee tarinan henkilöitä sen perushahmoihin.

${ }^{15}$ Novellissa "ihanasta nuoresta neidosta" käytetään muotoa Columbine. Samaa muotoa käytetään myös Canal Grandessa, joten jatkossa pitäydyn Raittilan käyttämään nimitykseen. Colombina-nimi muotoutui vallitsevaksi, mutta paljon muitakin on käytetty (Rudlin 1994, 127). Tuulin Columbine-hahmoisuus osoitetaan Canal Grandessa mutkan kautta: karnevaalin viimeisenä päivänä Tuuli pukeutuu Pulcinellaksi, ja Heikkilä selittää Marrasjärvelle, että "Columbine saattoi täällä olla nimeltään myös Pulcinella" (CG, 28I). 
Mä kysyin teenkö mä väärin, jos mä lopetan tilin ja vien Miriamilta rahat. Se sanoi, että hän ei voi päättää mun puolestani mitään, mutta mitä tahansa mä teen, niin mä voin aina tulla kertomaan. Ihminen yrittää ratkaista vajavaisella kyvyllään, mikä on oikein ja väärin, mutta kaikkien ihmisten ratkaisujen tuolla puolen armo on ja pysyy. Ei sitä ansaita. (CG, 326.)

Pappi vetoaa ensin Raamattuun: "Syntinen nainen ja ryöväri pelastuivat, mutta fariseus hukkui, koska armo seuraa uskoa eikä lakia." Pyhä teksti ei kuitenkaan vakuuta, koska vastaanottaja ei tunne tarinaa: "Kuka se fariseus on, mä kysyin ja pappi rupesi puhumaan avustusjärjestöistä, joihin Miriam voisi ottaa yhteyttä.” Tuuli keskeyttää:

Mikään järjestö ei rupea maksamaan viittäsataa euroa johonkin Moldovaan. - - Mä kysyin papilta, miksei se itse maksa omistaan. Se meni hiljaiseksi. Mutta ei sekään tuntunut ihan reilulta. (CG, 326.)

Kysymys asettaa lukijankin saman tilanteen eteen: vedotako avustusjärjestöihin, instituutioihin, hyväosaisempiin tai mihin tahansa muuhun, jotta vastuu hädässä olevasta lähimmäisestä siirtyisi itseltä pois?

Keskustelu jatkuu: "Pappi sanoi, että mä olen jo nyt pelastanut ihmishengen ja luultavasti pelastan sen aina uudestaan ja uudestaan sillä, että annan sen jatkaa tilinkäyttöä.” Tuuli purskahtaa nauruun ja alkaa kertoa Venetsian pelastamisoperaatiosta, "koko siitä mielettömästä projektista", ja kysyy samalla, mitä "ne on pystyneet pelastamaan valtuuskunnillaan ja hallituksillaan, komissioillaan ja yhteisvaluutoillaan?" Ja vastaa: "Marrasjärvi saatana pelasti yhden aasin avannosta!"16 Tähän ei pappi osaa sanoa mitään; hän menee ikkunaan ja rupeaa itkemään. Lopussa molemmat itkevät polvillaan lattialla toisiinsa tukeutuen, ja lapsi nykii Tuulin sisällä. Tuulin ratkaisu jää näin avoimeksi. (CG, 328.)

Loppukuvassa huomio kiintyy kohtauksen kompositioon, koska se rakentaa Tuulin hahmoon madonnamaisuutta, josta Raittila itsekin mainitsee. ${ }^{17}$ Pappi katsoo ensin ikkunasta ikään kuin ulkopuolelta ratkaisua 
hakien, mutta polvistuu sitten itkien Tuulin viereen. Kuva on kuin uskonnollinen maalaus, jossa tuleva äiti - madonna - lohduttaa ahdistunutta lähimmäistä.

Asetelmassa on myös muistuma ikonista, jota on luonnehdittu "ikkunaksi taivaaseen". On muistettava, että Tuuli on tuonut papille nähtäväksi saman ikonin, jota Saraspää kuljetti karnevaaliviittansa alla ja johon hän ennen kuolemaansa Tuulin ohella turvautui. Pappi selvittää Tuulille ikonin nimenkin: Kasanilainen Jumalanäidin kuolonuneen nukahtaminen. Lopussa pappikin turvautuu Tuuliin. Toisaalta ikkuna jo itsessään on vertauskuva Neitsyt Mariasta (Biedermann 2003, 84). Tuuli on kuitenkin hyvin moderni madonna; hänestä puuttuu kaikki kiiltokuvamaisuus, levollisuus ja seestyneisyys. Hän on itse asiassa hyvin hädissään, epävarma toimiensa ja päätöstensä järkevyydestä, täynnä ristiriitaisia ajatuksia. Siksi hän papille tilanteensa ja hätänsä paljastaakin. Tuuli muuttuu siis tarinan mittaan Columbine-hahmosta madonna-hahmoksi.

Hahmossa on kuitenkin vielä yksi ulottuvuus, johon romaani ei suoraan viittaa kuten se tekee commedia dell'arte -perinteen kohdalla mutta joka paljastuu sen kompositiota tutkimalla. Canal Granden tarina alkaa sumun keskeltä, ja suomalaisryhmä kulkee kaupungissa kuin sokea, hapuillen. Sankka sumu ja vielä sankempi byrokratia estävät kaikki pelastustoimet, joihin ainakin Marrasjärvi on vakavissaan ryhtymässä. Yhtenä päivänä alkaa kuitenkin käydä raikas tuuli, joka hajottaa sumun:

Sumu alkoi kulkea kovaa vauhtia ja repeili riekaleiksi. Samanlaiselta näyttää, kun lentokone sukeltaa pilvestä kirkkaaseen ilmaan. Tuulen työntämien usvalauttojen välistä rupesin näkemään kaupunkia, jossa olin pari viikkoa liikkunut aivan sokkona. (CG, 26.)

Tuuli hajottaa sumun. Tarinan muut henkilöt kulkevat kuin sumussa, mutta Tuulin kertomuksessa kuvatun maailman todellisuus näyttäytyy kirkkaassa valossa. Tuuli näkee selvimmin kulissien ja naamioiden taakse, rakenteisiin saakka. Johanneksen evankeliumissa Jeesus sanoo: "Tuuli puhaltaa, missä tahtoo, ja sinä kuulet sen huminan, mutta et tiedä, mistä se tulee ja minne se menee; niin on jokaisen, joka on Hengestä syntynyt" (Joh. 3: 8). Katkelma liittyy keskusteluun Pyhän Hengen luomasta uudesta elämästä ja ihmisten pelastamisesta. ${ }^{18}$ Evankeliumikertomuksella ja Raittilan romaanilla on yhdistävä teema: hukkuvan pelastaminen ja toisten puolesta uhrautuminen. Yhdistäjänä on myös tuuli, joka puhaltaa, missä tahtoo. ${ }^{19}$

änsä miksikään ihanaksi suojelusenkeliksi, mutta romaanin kompositiossa hänet voi sellaiseksi tulkita, koska hän saattaa turvaan kuolemanvaarassa olevan moldovalaisen Miriamin.

${ }^{18}$ Samassa yhteydessä Jeesus sanoo: "Sillä niin on Jumala maailmaa rakastanut, että hän antoi ainokaisen poikansa, ettei yksikään, joka häneen uskoo, hukkuisi, vaan hänellä olisi iankaikkinen elämä” (Joh. 3: 16).

${ }^{19}$ Raamatussa tuuli on Jumalan ja Pyhän Hengen vertauskuva: helluntaipäivänä Pyhä Henki näyttäytyy paitsi "tulisina kielinä" myös tuulena, tuulenpuuskana. Ks. Apt. 2: I-4. "Jumala on Henki", sanotaan Johanneksen evankeliumissa (4: 24), mutta hepreankielinen käsite ruach voidaan kääntää myös ilman liikkeeksi, tuuleksi, henkäykseksi tai hengitykseksi. (McGrath 1997, 279-28I; Palva 1995, 322-326.) 
Tuulia voi pitää tarinan myös Kristus-hahmona. Johanneksen evankeliumissa puhutaan hyvästä paimenesta, joka jättää 99 turvassa olevaa pelastaakseen yhden kadoksiin joutuneen lampaan, ja Jeesus viittaa myös itseensä hyvänä paimenena, joka uhraa henkensä lampaitten puolesta. Romaani viittaa taitavasti - taideteoksen kautta - tähän evankeliumeissa toistuvaan lammas-paimen-symboliikkaan. Gardajärvellä suomalaiset majoittuvat hotelliin, jonka nimi on Albergo Caritas. Dosentin ja insinöörin huoneessa on seinämaalaus, jossa Jeesus on kantamassa "vertavuotavaa lammasta":

Lammas oli jumalattoman iso, eikä Jeesus pitänyt sitä poikittain hartioilla, kuten yleensä vastaavissa kuvissa, vaan reppuselässä kuin ihmistä. Taustalla oli lauma, jonka Jeesus oli jättänyt pelastaakseen tämän yhden. Kuvan alla oli tekstiä latinaksi, ei italiaksi: "Yksikään, joka minuun uskoo, ei huku”, dosentti käänsi. (CG, 213.)

Maalaus, raamatunlause ja majatalon nimi liittyvät kaikki romaanin pelastus-teemaan. Samaan aikaan kun seurueen pölvästijäsenet tuijottavat maalausta keskittyen sen tekniseen puoleen ("Kielsin särkemästä rappinkia. Se [dosentti] selitti aikoneensa vain tutkia oliko maalaus tehty freskotekniikalla"), Tuuli on käyttämässä heroiinin vahingoittamaa (verta vuotavaa) Miriamia lääkärillä ja toimittamassa tätä Itävallan puolelle. Hän on ikään kuin kantamassa turvaan lammasta, pelastamassa hukkuvaa; lampaastakin sanotaan, että sitä kannetaan kuin ihmistä. Tuuli on Kristushahmo - hyvä paimen ja pelastaja - jolle hädässä oleva ihminen on arvokkaampi kuin Venetsia ja sen taideaarteet. ${ }^{20}$ Hän osoittautuu lopulta tarinan ainoaksi sankariksi, laupiaan samarialaisen henkiseksi perilliseksi, tätä kuitenkaan itse tiedostamatta.

\section{Talvisesta kaupungista keväiseen viinitarhaan}

Canal Grande viittaa lukemattomiin taideteoksiin ja tunnettuun Venetsiamytologiaan, operoi toisistaan jyrkästi erottuvilla kertojanäänillä ja pelaa tietoisesti kirjallisilla kliseillä. Karnevaalimaailmankuvaan tukeutuen romaani saattaa yhteen etäällä toisistaan olevia arvoja, ajatuksia ja ilmiöitä. Kuten Bahtin (199I, I8I) sanoo, "karnevaali lähentää, yhdistää, kihlaa ja liittää pyhän maalliseen, ylevän alhaiseen, suuren mitättömään, viisaan tyhmään jne.”. Keskeiset henkilöt rakentuvat sekä stereotypioille että rikkaalle karnevaaliperinteelle.

Karnevaalin tavoin romaani problematisoi sosiaaliset hierarkiat, toden ja epätoden, faktan ja fiktion. Henkilöt pohtivat tarinoiden ja todella tapahtuneen suhdetta, puhuvat naamioista ja kulisseista, osallistuvat oikeaankin karnevaaliin ja ovat kaiken lisäksi - tietämättään - mukana

${ }^{20}$ Markku Envall on jakanut kirjallisuuden Kristus-hahmot kahteentoista erilaiseen tyyppiin (1985, 92-140). Jaottelu on periaatteessa kiinnostava mutta käytännössä ymmärrettävästi puutteellinen. Siitä puuttuu esimerkiksi "hyvä paimen" ja "pelastaja", jollaiseksi Tuuli Raittilan romaanissa hahmottuu. 
tuhoisia muotoja saavassa näytöksessä, jossa naamioiden suojassa tehdään rikoksia ja käydään kauppaa jopa ihmishengillä.

Canal Grandea luonnehtii karnevaaliin sisältyvä ajatus uudistumisesta ja vaihtuvuudesta. Alun leikkisät vastakkainasettelut (pohjoinenetelä, moderni-perinteinen, fakta-fiktio, varautuminen-huolettomuus jne.) vähenevät tarinan edetessä, ja siirryttäessä Talvi-luvusta Kevätlukuun romaani vakavoituu. Tuulin ja papin dialogista rakentuu romaanin eettinen kysymyksenasettelu: mitä voi yksittäinen ihminen tehdä vääryyksiä ja rikoksia nähdessään tai inhimillisen hädän ja avuntarpeen keskellä? Ja miksi vain jotkut näkevät asioiden oikeat mittasuhteet toisten kulkiessa oppineisuudestaan ja teknisistä apuvälineistään huolimatta kuin sumussa - tai oppineisuuden ja teknisten apuvälineiden muodostamassa sumussa?

Vanha väsähtänyt maailma, jota Venetsia tapahtumapaikkana kuvastaa, vajoaa Saraspään mukana, mutta Tuulin pyyteetön lähimmäisenrakkaus ja rohkea toiminta luovat uutta. Uuden syntymistä symboloi myös Tuulin raskaus. Vajoavasta ja sumuisesta kaupungista siirrytään maalle, keväiseen viinitarhaan, jossa uusi elämä versoo. Tarinan päätöksessä voi nähdä myös evankeliumikertomuksista kumpuavaa symboliikkaa: uusi viini lasketaan uusiin leileihin.

\section{LÄHTEET \\ Kaunokirjallinen aineisto}

Dickens, Charles 2008/I852-53: Kolea talo. Alkuteoksesta Bleak house suomentanut Kersti Juva. Helsinki: Tammi.

Hemingway, Ernst 1970/1950: Joen yli puiden siimekseen. Alkuteoksesta Across the River and into the Trees suomentanut Tauno Tainio. Helsinki: Tammi.

Leino, Eino 193 I/I899: Helsinki sumussa. Ajan aalloilla, Kootut teokset I. Helsinki: Otava.

Mann, Thomas 1985/I912: Kuolema Venetsiassa ja muita kertomuksia. Alkuteoksesta Erzählungen suomentanut Oili Suominen, Eeva-Liisa Manner ja Aarno Peromies. Helsinki: Tammi.

Raittila, Hannu 1994: Garibaldino Finlandese. Ilmalaiva Finlandia. Novelleja. Porvoo - Helsinki - Juva: WSOY.

Raittila, Hannu 1998: Ei minulta mitään puutu. Porvoo - Helsinki - Juva: WSOY.

Raittila, Hannu 200 I: Canal Grande. Helsinki: WSOY. (= CG)

Raittila, Hannu 2003: Atlantis. Romaani. Helsinki: WSOY.

Raittila, Hannu 2010: Marsalkka. Helsinki: Siltala.

Raittila, Hannu 2013: Terminaali. Romaani. Helsinki: Siltala.

Tuuri, Antti 1982: Pohjanmaa. Romaani. Helsinki: Otava. 
Tuuri, Antti 1984: Talvisota. Kertomus. Helsinki: Otava.

\section{Muut lähteet}

Bahtin, Mihail I99I/I963: Dostojevskin poetiikan ongelmia. Alkuteoksesta Problemy poetiki Dostojevskogo suomentaneet Paula Nieminen ja Tapani Laine. Orient Express.

Bahtin 2002/1965: François Rabelais - keskiajan ja renessanssin nauru. Alkuteoksesta Tvorshestvo Fransua Rable i narodnaja kultura srednevekovja i renessansa suomentanut Tapani Laine ja Paula Nieminen. Kolmas painos. Helsinki: Like.

Biedermann, Hans 2003/I989: Suuri symbolikirja. Alkuteoksesta Knaurs Lexikon der Symbole suomentanut ja toimittanut Pentti Lempiäinen. Helsinki: WSOY.

Envall, Markku 1985: Nasaretin miehen pitkä marssi. Esseitä Jeesusaiheesta kirjallisuudessa. Porvoo - Helsinki - Juva: WSOY.

Hökkä, Tuula 1999: Modernismi: uusi alku - vanhan valtaus. Suomen kirjallisuushistoria 3. Rintamakirjeistä tietoverkkoihin. Toim. Pertti Lassila. Helsinki: SKS, 82-85.

Karonen, Vesa 200I: Hannu Raittila vie Suomen Venetsiaan. Helsingin Sanomat 26.8.200I.

Laitinen, Kai 1958: Puolitiessä. Esseitä kirjallisuudesta. Helsinki: Otava.

McGrath, Alister E. 1997/1994: Christian Theology. An Introduction. Second Edition. Cambridge, Mass. and Oxford: Blackwell.

Nicoll, Allardyce 1963: The World of Harlequin. A Critical Study of the Commedia dell' Arte. Cambridge: Cambridge University Press.

Palva, Heikki 1995: Raamatun tietosanasto. Porvoo - Helsinki - Juva: WSOY.

Pesonen, Pekka 1982: Uusmytologismi: näkökulma modernismiin. - Kirjallisuudentutkijain Seuran vuosikirja 34. Toim. Auli Viikari. Helsinki: SKS, 153-168.

Pesonen, Pekka 1987: Vallankumouksen henki hengen vallankumouksessa. Tutkielma Andrei Belyin romaanista "Peterburg" ja sen aatetaustasta. Helsinki: Slavica Helsingiensia Supplementum II.

Pesonen, Pekka 199I: Dialogi ja tekstit. Bahtinin, Lotmanin ja Mintsin virikkeitä intertekstuaalisuuden tutkimiseen. Intertekstuaalisuus. Suuntia ja sovelluksia. Toim. Auli Viikari. Helsinki: SKS, 3I-58.

Raamattu 1962. Suomen evankelilais-luterilaisen kirkon kirkolliskokouksen vuosina 1933 ja 1938 käyttöön ottama suomennos. Helsinki: Suomen Pipliaseura. 
Raittila, Hannu 2002: Rahat vai kolmipyörä ja muita kirjoituksia. Helsinki: WSOY.

Raittila, Hannu 2006: Kirjailijaelämää. Helsinki: WSOY.

Rudlin, John I994: Commedia dell' Arte. An Actor's Handbook. London and New York: Routledge.

Suojanen, Sami 2004: Suojelkaa kiilusilmäkommunistit [Hannu Raittilan haastattelu]. Aamulehti 25.4.2004.

Tarkka, Pekka I980: Suomalaisia nykykirjailijoita. Uusi laitos. Helsinki: Tammi.

Viikari, Auli 1992: Ei kenenkään maa. 1950-luvun tropologiaa. Avoin ja suljettu. Kirjoituksia 1950-luvusta suomalaisessa kulttuurissa. Toim. Anna Makkonen. Helsinki: SKS, 30-77.

\section{Kirjoittaja}

Juhani Sipilä, FT, yliopistonlehtori, Helsingin yliopisto, kotimainen kirjallisuus (juhani.sipila[at]helsinki.fi)

Joutsen / Svanen 20I4. ISSN 2342-2459

www.helsinki.fi/kirjallisuuspankki/joutsen-svanen-20/4 